\title{
Laryngeal edema is common in HAE and demands preventive measures
}

\author{
Cristine Secco Rosario , Ana Flavia Machado, Jose Eduardo Thomaz, Camila Piragine, Alessandra Bitencourt, \\ Isabela D'agulham, Herberto Jose Chong Neto, Carlos Antônio Riedi, Nelson Rosario Filho
}

From 3rd WAO International Scientific Conference (WISC) 2014

Rio de Janeiro, Brazil. 6-9 December 2014

\section{Background}

The aim of this study was to show the clinical characteristics and treatment of Hereditary Angioedema (HAE) in a tertiary center from Curitiba, south of Brazil.

\section{Methods}

A cross-sectional study reviewing records of patients in the Hospital de Clínicas, Federal University of Paraná. We analised the clinical characteristics, laboratory tests and treatment of patients with HAE.

\section{Results}

Forty two patients, male (45\%), age mean $27.1 \pm 16.9$ years. Symptoms started at median age 14 years (range 1 to 58 ys.). Thirty seven (86\%) had familial history of HAE. They had a median of 2 episodes/mo (range 0.2 to 30$)$ lasting $3 \pm 1.7$ days/episode. Edema of limbs, face, genital and laryngeal, abdominal pain, diarrhea and vomiting were seen in $73.8 \%, 52.4 \%, 23.8 \%, 17 \%, 81 \%$, $24 \%$ and $38.1 \%$, respectively. Twenty four $(57 \%)$ had low C4 level, mean serum level of C4=12.7 $\pm 10.6 \mathrm{mg} / \mathrm{dL} ; 26$ (62\%) had low levels of $\mathrm{C} 1$ esterase inhibitor, 4 (9.5\%) had low functional $\mathrm{C} 1$ esterase inhibitor and 12 (28.6\%) had C1q deficiency and 3 (7.1\%) had HAE type III confirmed. Fifteen $(28.9 \%)$ were treated with Danazol $175 \pm 134 \mathrm{mg} /$ day, 15 (28.9\%) were using tranexamic acid as needed. No patient had Icatibant access.

\section{Conclusions}

HAE is a difficult to control disease. Patients needs to have a facilitated access to newer therapies to control their symptoms and reduce the adverse events of Danazol.

Federal University of Paraná, Brazil

(c) 2015 Rosario et al; licensee BioMed Central Ltd. This is an Open Access article distributed under the terms of the Creative Commons Biomed Central
Published: 8 April 2015

doi:10.1186/1939-4551-8-S1-A190

Cite this article as: Rosario et al:: Laryngeal edema is common in HAE and demands preventive measures. World Allergy Organization Journal 2015 8(Suppl 1):A190.
Submit your next manuscript to BioMed Central and take full advantage of:

- Convenient online submission

- Thorough peer review

- No space constraints or color figure charges

- Immediate publication on acceptance

- Inclusion in PubMed, CAS, Scopus and Google Scholar

- Research which is freely available for redistribution

Submit your manuscript at www.biomedcentral.com/submit
C Biomed Central 